\title{
Results of Practical Use of Fertilizers from Chicken Manure in Winter Wheat Cultivation
}

\author{
F.S. Sibagatullin, Z.M. Khaliullina, R.R. Minnikhanov, A.S. Ganiev and I.Kh. Gayfullin*
}

Kazan State Agrarian University, Kazan, Russia

\begin{abstract}
The article considers utilization of organic waste from poultry farming being an urgent problem of agriculture. Leaders of large poultry farms are interested in using low-cost recycling schemes aimed to process waste into safe products in a short time. This paper considers the possibility of using an organic fertilizer "Soil Improver (UP-1)" obtained by processing poultry waste by using a biologically active additive Mefosfon, which is a melamine salt of bis (oxymethyl) phosphinic acid. Field tests were carried out in 2019-2020 on the lands of OAO "Agrofirma "Ak Bars-Pestretsy" being the branch of the Poultry farm of the Pestrechinsky district of the Republic of Tatarstan. The object of the study was the recognized variety of soft winter wheat "Scepter" ES (elite variety). The rate of application of chicken compost and organic product UP-1 in the control and experimental plots was 56 tons per 1 ha. The experimental data show that wheat cultivated with the application of UP-1 compost was distinguished by higher rates of field germination (increased by $13 \%$ ); the length of secondary roots was $11.2 \%$ greater compared to control. The grain produced in this variant had higher hardness (control - $62 \%$, UP-1 - $72 \%$ ) and the quality of crud gluten $(74.0,78.0 \%$, respectively), the yield of winter wheat grain - by $0.06-0.12 \mathrm{t} / \mathrm{ha}(1.2-2.5 \%)$, which indicates the feasibility of using fertilizer from poultry manure in crops cultivation.
\end{abstract}

\section{Introduction}

The most important soil property providing an objective possibility of intensifying agriculture and being the basis for the sustainable development of the agrarian complex, is its fertility determined by the content of mineral and organic substances in it [1-3].

As a result of the activities of enterprises of the agroindustrial complex, there is a decrease in the soil content of humus, reserves of mineral nutrients, which, in some cases, leads to their balance violation, creates the preconditions for the intensification of degradation processes in the soil [4-6].

The dynamic development of poultry farming in the Russian Federation has led to an increase in the amount of waste hazardous to the environment and, predominantly, poultry manure. At the same time, poultry manure is a resource for obtaining organic fertilizer with valuable properties. The variety of forms of litter application enables to choose the most economically justified option for specific areas, cultivated crops [7].

Manure disposal technologies can solve two main problems: increasing soil fertility and protecting the environment. Utilization of poultry manure by soil method is justified in ecological and agro-economic terms.

In this regard, the development and testing of biotechnological processes for the disposal of organic waste from poultry farming, which ensure an effective product of complex action and its subsequent use in agricultural production, is relevant for science and practice.

The research aimed to conduct field trials on growing winter wheat using composted manure and organic fertilizer "Soil Improver (UP-1)" obtained using the Mefosfon preparation.

To achieve the goal, the following tasks were solved:

- to obtain organic fertilizer "Soil Improver (UP-1)" from poultry manure according to the previously developed technology;

- to assess the rate of products maturation, the level of bacterial contamination;

- to conduct comparative observations of the growth and development of winter wheat plants of the "Scepter" ES variety on control plots with composted chicken manure and experimental plots with UP-1 product;

- to compare the technological characteristics of grain obtained on control and experimental plots.

\section{Conditions, materials and research methods}

During the research, poultry manure from the poultry farm OAO "Poultry complex "Ak bars" of the poultry unit OOO "Holding company "Ak bars" was used. The organic fertilizer and organic product "Soil Improver (UP-1)" were obtained from the manure by means of classical composting and composting using the preparation "Mefosfon".

\footnotetext{
Corresponding author: Ilnur-gai@yandex.ru
} 
Field pilot tests were carried out in 2019-2020 on the lands of OAO "Agrofirma "Ak Bars-Pestretsy", a branch of the Poultry Farm of the Pestrechinsky District of the Republic of Tatarstan (Table 1). The lands were represented by light gray forest medium loamy soil with the following characteristics: humus - 2.3-3.0 \%; pHsol - 5.3-7.0; alkaline hydrolysable nitrogen $-81.2 \mathrm{mg} / \mathrm{kg}$; mobile phosphorus - 134-295 mg/kg; exchangeable potassium - 90-170 mg/kg; zinc - 0.34-1.08 mg/kg; cobalt $-0.62-1.0 \mathrm{mg} / \mathrm{kg}$; manganese $-29.6-43.8 \mathrm{mg} / \mathrm{kg}$; molybdenum - 0.11-0.15 mg/kg; copper - 5.3-7.2 mg/kg; sulfur $-4.81-8.01 \mathrm{mg} / \mathrm{kg}$; boron $-0.96-1.40 \mathrm{mg} / \mathrm{kg}$.

The bulk density of the arable layers $(0-30 \mathrm{~cm})$ was $1.3 \mathrm{~g} / \mathrm{cm}^{3}$, the maximum hygroscopicity in the arable layer ranged from 2.0 to $2.4 \%$, the reserves of productive moisture at the lowest or maximum field moisture capacity before sowing were $180-210 \mathrm{~mm}$ in 1 meter soil layer.

To destroy root-sprouting weeds, disking (BDT) was carried out to a depth of $12-14 \mathrm{~cm}$ followed by dual treatment with an interval of 2 weeks with a heavy discator TAD- $8 \times 2$ immediately after harvesting the sunflower at the end of July 2019 [10].

For crushing crop residues, efficient mixing of the applied fertilizers, loosening and reconsolidation two weeks before sowing and on the day of sowing, the soil was cultivated with a cultivator Tiger MT produced by Horsch with a disc running depth of up to $15 \mathrm{~cm}$ [11].

Chicken compost and UP-1 product were evenly applied by the method of spreading by a KamAZ HTKh15 tractor with a METAL-FACH N272/3 VIKING trailer (manure spreader) to experimental and control plots (Table 1).

Table 1. Variants of field experiments

\begin{tabular}{|c|c|c|}
\hline Variant & Fertilizer used & Area, ha \\
\hline Control & $\begin{array}{c}\text { Plot with composted chicken } \\
\text { manure }\end{array}$ & 3.38 \\
\hline $\begin{array}{c}\text { Experiment } \\
1\end{array}$ & $\begin{array}{c}\text { Plot with UP-1 with pre-sowing } \\
\text { treatment of grain with } \\
\text { biological products (nitrogen- } \\
\text { fixing and phosphate-mobilizing } \\
\text { bacteria) }\end{array}$ & 5.94 \\
\hline $\begin{array}{c}\text { Experiment } \\
2\end{array}$ & $\begin{array}{c}\text { Plot with UP-1 with pre-sowing } \\
\text { grain processing with Mefosfon }\end{array}$ & 5.72 \\
\hline
\end{tabular}

The rate of chicken compost and organic product UP1 application in the control and experimental plots was 56 tons per 1 ha (Table 2).

In field experiments, the object of research was the recognized species of soft winter wheat "Scepter" ES, a variety of lutescens Mid-season with the following characteristics: $282-336$ days growing season, increased winter hardiness, high resistance to spring frost, average drought resistance, resistance to lodging. It does not crumble with prolonged over-growing on the vine. It is valuable wheat. The mass of 1,000 grains is $38-49 \mathrm{~g}$. The content of gluten is 22.1-30.8\%, protein $12.3-15.6 \%$. This variety is resistant to head smut, moderately resistant to brown rust and yellow spot. It is slightly affected by powdery mildew, septoria and root rot and susceptible to snow mold.
Table 2. Agrochemical characteristics of soil on control and experimental plots before and after applying organic fertilizers

\begin{tabular}{|c|c|c|c|c|c|}
\hline \multirow{2}{*}{ No. } & Indicator & \multicolumn{4}{|c|}{ Content } \\
\cline { 3 - 6 } & & $\begin{array}{c}\text { Before } \\
\text { applica } \\
\text { tion }\end{array}$ & \multicolumn{2}{|c|}{ After application } \\
\cline { 3 - 6 } & Control & $\begin{array}{c}\text { Experi } \\
\text { ment 1 }\end{array}$ & $\begin{array}{c}\text { Experi } \\
\text { ment 2 }\end{array}$ \\
\hline 1 & Aqueous extract pH & 7.3 & 6.8 & 6.7 & 7.0 \\
\hline 2 & Salt extract pH & 6.4 & 7.3 & 7.2 & 6.3 \\
\hline 3 & $\begin{array}{c}\mathrm{K}_{2} \mathrm{O} \text { (mobile potassium } \\
\text { compounds), mg/kg }\end{array}$ & 273 & 605 & 672 & 722 \\
\hline 4 & $\begin{array}{c}\mathrm{P}_{2} \mathrm{O}_{5} \text { (mobile } \\
\text { phosphorus } \\
\text { compounds), mg/kg }\end{array}$ & 297 & 489 & 524 & 934 \\
\hline 5 & $\begin{array}{c}\text { Mass fraction of } \\
\text { organic substances, \% }\end{array}$ & 3.97 & 6.81 & 6.92 & 6.36 \\
\hline 6 & $\begin{array}{c}\text { Sodium (gross content), } \\
\text { mg/kg }\end{array}$ & 108 & 102 & 118 & 137 \\
\hline 7 & $\begin{array}{c}\text { Alkaline hydrolysable } \\
\text { nitrogen, mg/kg }\end{array}$ & 123 & 629 & 458 & 493 \\
\hline
\end{tabular}

Sowing was carried out on August 29, 2019 with a HORSCH PRONTO seeding unit, seeding rate of 5.5 million seeds/ha. The air temperature during sowing was $15{ }^{\circ} \mathrm{C}$, the soil temperature was $14{ }^{\circ} \mathrm{C}$. The experiments were repeated three times, variants placement was systematic.

During the tests, the agrotechnology of crop cultivation generally accepted for the Republic of Tatarstan was used.

Autumn feeding with mineral fertilizers in the tillering phase of winter wheat was carried out on September 16, 2019 [12].

Azofoska was used as a mineral fertilizer at the rate of $150 \mathrm{~kg} / \mathrm{ha}$, the method of application was a grain seeder SZ-3.6 being a unit with an MTZ-80 tractor $[13,14]$.

Foliar treatment of plants in the tillering phase with the studied preparations was carried out on October 4, 2019 with a Challenger ROGATOR sprayer in accordance with the experimental scheme.

In the experiments, the field germination of seeds and biometric parameters of plants were determined [15]. When determining the field germination of grain crops on a conventional row crop with $15 \mathrm{~cm}$ row spacing, areas of $1,000 \mathrm{~cm}^{2}\left(1 / 10 \mathrm{~m}^{2}\right.$, two rows $33.3 \mathrm{~cm}$ long, $30 \mathrm{~cm}$ wide) were allocated. The number of seedlings was counted on the designated plots. The average was determined from 10 calculations and recalculated to $1 \mathrm{~m}^{2}$.

Phenological observations on the phases of plant development were carried out according to the methodology of the State Variety Testing (1985).

Plot harvesting from all three plots was carried out on July 25, 2020 with a NewHolland CX 6090 combine. Grain from each plot was collected in separate bags for further quality analysis. At the end of the growing season and harvesting, the yield and quality of grain were assessed [16].

Crops weediness was determined quantitatively at the rate of $\mathrm{pcs} / \mathrm{m}^{2}$ using the framework [17].

Poultry manure, compost and soil with regards to agrochemical, microbiological, sanitary-parasitological, sanitary-entomological, chemical-toxicological indicators were analyzed in certified laboratories of the 
Federal State Budgetary Institution "Tatar Interregional Veterinary Laboratory" and the State Budgetary Institution "Republican Veterinary Laboratory of the Republic of Tatarstan". The quality of the composting organic fertilizers was assessed according to SanPiN 2.1.7.1287-03, GOST R 53117-2008. Organic fertilizers [2.1.7]. Soil, cleaning of populated areas, household and industrial waste, sanitary protection of soil. Sanitary and epidemiological requirements for soil quality Sanitary and epidemiological rules and standards SanPiN 2.1.7.1287-03)

The number of coliform bacteria and enterobacteria was determined according to the methodological recommendations (No. FC/4022 approved on 24.12.2004) [18].

The harvested crop was analyzed in terms of organoleptic and physicochemical indicators in the accredited laboratory of the Federal State Budgetary Institution "Federal Center for Evaluation of the Safety and Quality of Grain and Processing Products" and in terms of chemical composition and technological properties - in the laboratory of the Tatar Research Institute of Agriculture of the Federal State Budgetary Institution Federal Research Center "Kazan Scientific center of RAS".

The experimental data were processed according to B.A. Dospekhov (1985) [17] using Microsoft Excel and a personal computer.

\section{Analysis and discussion of research results}

From March to May 2019, the UP-1 product was obtained by treating 7,400 tons of chicken manure with Mefosfon at the rate of $8.5 \mathrm{ml} / \mathrm{t}$ and using a specialized vehicle "DUK". On May 13-15, 2019, processed and unprocessed chicken manure were taken out to the field of OAO "Agrofirma "Ak Bars-Pestretsy" located in the Pestrechinsky district of the Republic of Tatarstan, where it was laid in piles until being fully matured. The fermentation process was controlled according to the content of unconditionally pathogenic microflora, compost temperature, organoleptic indicators.

According to the analysis as of July 2, 2019, the compost and the UP-1 product were free of pathogenic microorganisms, sulfite-reducing bacteria, intestinal pathogenic protozoan cysts, helminth eggs and larvae, larvae and pupae of synanthropic flies. The content of coliform bacteria and enterococci in UP-1 was less than $10 \mathrm{CFU} / \mathrm{g}$, which indicates the compliance of the obtained product with the requirements of GOST R 53117-2008.

In terms of the content of heavy metals (lead, cadmium, mercury), arsenic, natural and technogenic radionuclides, the obtained organic fertilizers met the requirements for organic fertilizers from poultry waste (GOST R 53117-2008, NRB-99/2009).

\section{Field experiments}

In autumn, after sowing winter wheat, the meteorological conditions were characterized by slight deviations in temperature. Thus, in September, the average monthly temperature was $0.8-1.7^{\circ} \mathrm{C}$ below the norm; the average monthly actual temperatures in October and November were 3.1 and $1.3{ }^{\circ} \mathrm{C}$ above the norm. The amount of precipitation varied greatly. Specifically, in August, 2019 there were $174 \%$ precipitation of the norm, in September and November their amount equaled to 53 and $63 \%$ less (Figure 1).

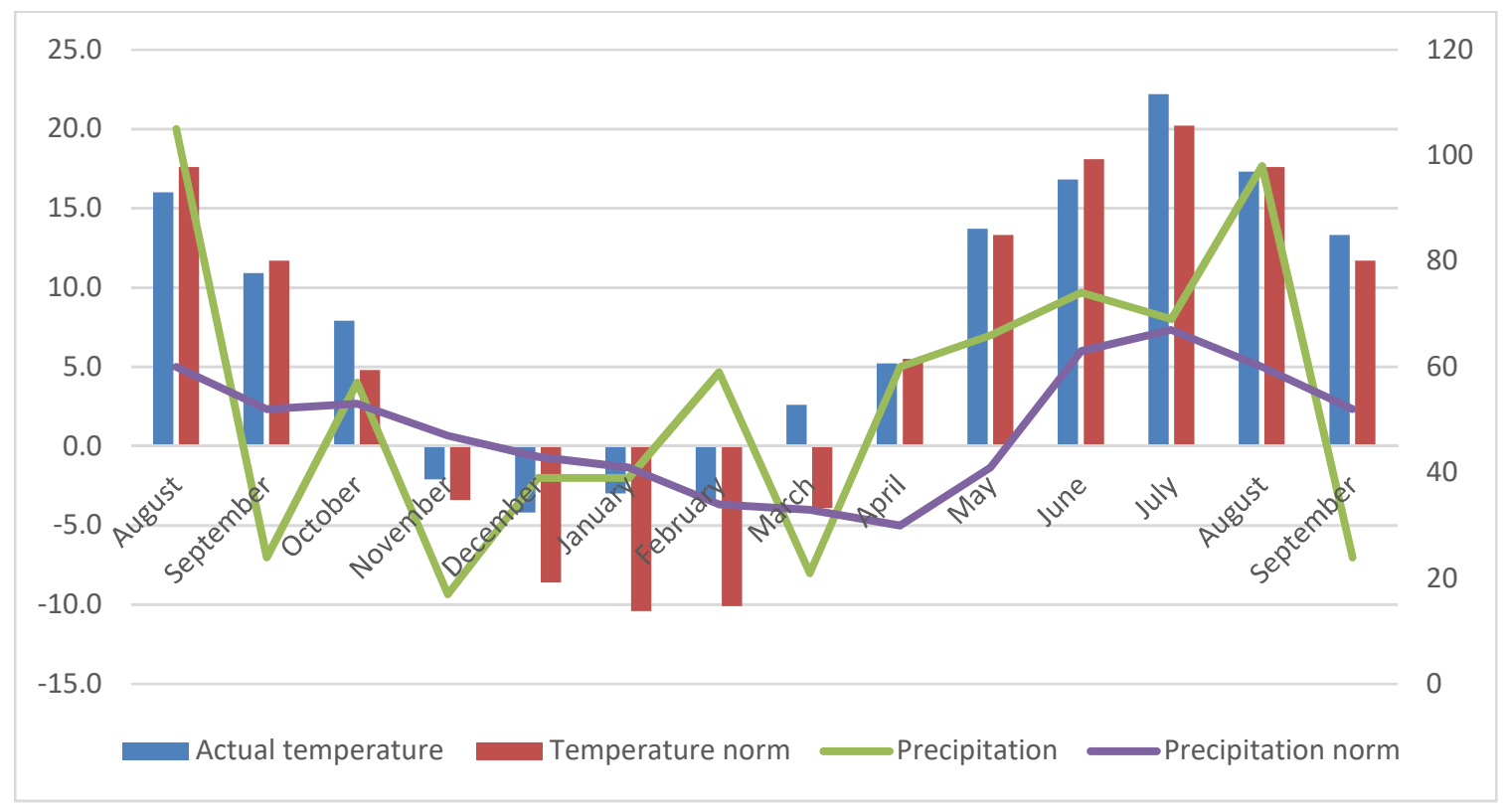

Fig. 1. Meteorological conditions during the period of growing winter wheat. 
The growth and formation of plants at the initial stages of development determines its ability to successfully overwinter. Therefore, phenological observations of winter wheat in control and experimental plots were carried out in the autumn growing season.

The first seedlings of plants were recorded 5-6 days after sowing; the full germination phase was recorded on September 12, 2019 (Table 3).

Table 3. Biometric indicators of wheat during initial growth (September 14, 2019)

\begin{tabular}{|c|c|c|c|c|}
\hline Variant & $\begin{array}{c}\text { Seedling } \\
\text { height, cm }\end{array}$ & $\begin{array}{c}\text { Coleoptile } \\
\text { length, cm }\end{array}$ & $\begin{array}{c}\text { Root } \\
\text { length, cm }\end{array}$ & $\begin{array}{c}\text { Number } \\
\text { of roots, } \\
\text { pcs }\end{array}$ \\
\cline { 2 - 5 } & \multicolumn{4}{|c|}{ cm } \\
\hline Control & 8.5 & 2.1 & 9.9 & 4.4 \\
\hline Experiment 1 & 9.0 & 2.5 & 10.4 & 4.1 \\
\hline Experiment 2 & 9.1 & 2.1 & 10.7 & 4.0 \\
\hline LSD $_{0,5}$ & 1.2 & 1.2 & 1.4 & 1.2 \\
\hline
\end{tabular}

It should be noted that the laboratory germination of seeds in all variants had comparable values, and the field germination in the control was $13.3 \%$ lower than in the experimental variants (Table 4 ).

Table 4. Indicators of germination and germination energy of seeds of winter wheat varieties Scepter ES

\begin{tabular}{|c|c|c|c|}
\hline \multirow{2}{*}{ Variant } & \multicolumn{2}{|c|}{ Germination, \% } & Germinatio \\
\cline { 2 - 4 } & Field & Laboratory & $\begin{array}{c}\text { energy, } \\
\text { \% }\end{array}$ \\
\hline Control & 84.0 & 97.3 & 96.0 \\
\hline Experiment 1 & 95.3 & 97.3 & 96.7 \\
\hline Experiment 2 & 96.3 & 98.0 & 96.7 \\
\hline
\end{tabular}

Measurements of biometric indicators in 2020 in field experiments, differences between the experiment and control in the germination rate and time of full germination were not observed, the average height of seedlings and the length of plant roots on the control plot was less than on the experimental plot (Figure 2, 3).

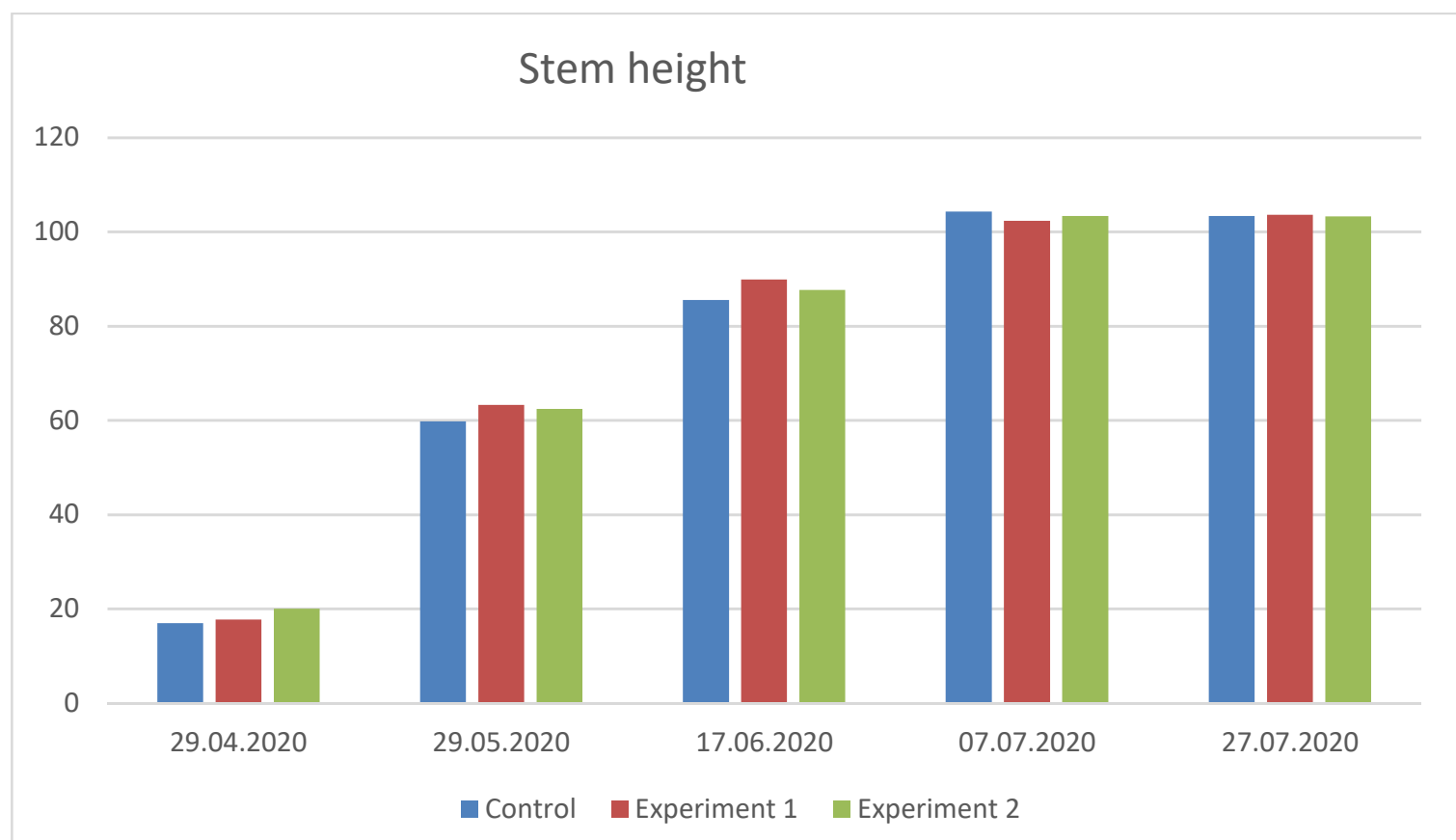

Fig. 2. Change in average height of stem of winter wheat plants during growing season 


\section{Root length}

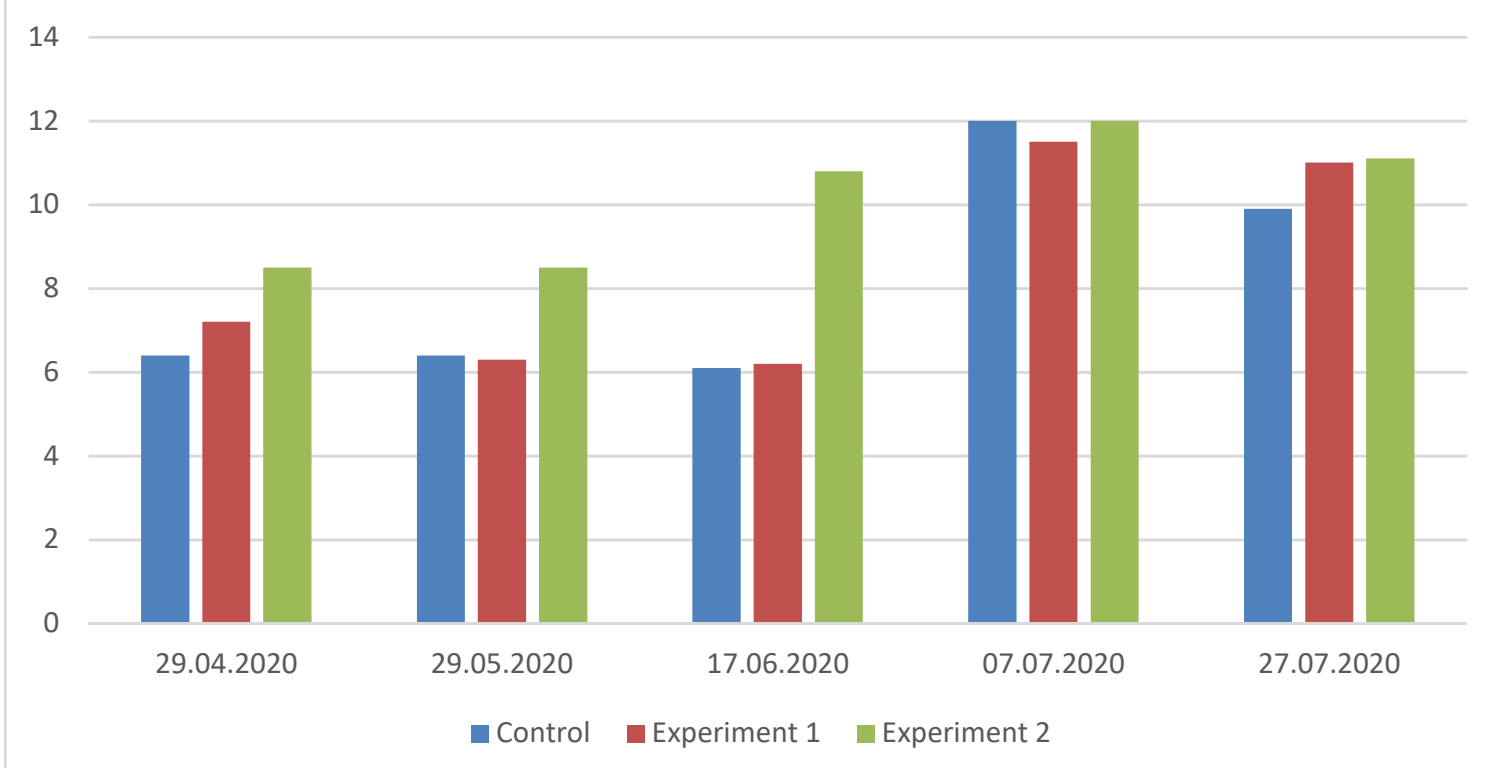

Fig. 3. Change in average length of roots of winter wheat plants during growing season

Table 5. Characteristics of winter wheat at different stages of development

\begin{tabular}{|c|c|c|c|c|c|}
\hline $\begin{array}{c}\text { Phase } \\
\text { (selection } \\
\text { date) }\end{array}$ & Indicator & ن் & 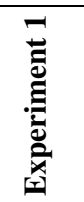 & 坣 & \\
\hline \multirow{4}{*}{$\begin{array}{l}\text { Bushiness } \\
(29.04 .20)\end{array}$} & Stem height, $\mathrm{cm}$ & 17.0 & 20.0 & 17.7 & 1.4 \\
\hline & Stem thickness, mm & 1.2 & 2.2 & 1.6 & 1.2 \\
\hline & $\begin{array}{c}\text { Average weight of dry } \\
\text { stem, g }\end{array}$ & 1.6 & 2.0 & 1.8 & 1.2 \\
\hline & $\begin{array}{c}\text { Secondary root length, } \\
\mathrm{cm}\end{array}$ & 6.4 & 8.5 & 7.2 & 1.3 \\
\hline \multirow{3}{*}{$\begin{array}{c}\text { Stem } \\
\text { elongation } \\
(29.05 .20)\end{array}$} & Stem height, $\mathrm{cm}$ & 59.8 & 62.4 & 63.3 & 1.4 \\
\hline & $\begin{array}{l}\text { Average weight of dry } \\
\text { stem, g }\end{array}$ & 1.17 & 1.38 & 1.25 & 1.2 \\
\hline & $\begin{array}{c}\text { Secondary root length, } \\
\mathrm{cm}\end{array}$ & 6.5 & 8.6 & 7.4 & 1.2 \\
\hline \multirow{4}{*}{$\begin{array}{l}\text { Heading } \\
(17.06 .20)\end{array}$} & Stem height, $\mathrm{cm}$ & 85.5 & 87.7 & 89.9 & 1.6 \\
\hline & $\begin{array}{l}\text { Average weight of dry } \\
\text { stem, g }\end{array}$ & 1.90 & 2.63 & 2.10 & 1.2 \\
\hline & $\begin{array}{c}\text { Secondary root length, } \\
\mathrm{cm}\end{array}$ & 7.5 & 10.8 & 8.4 & 1.2 \\
\hline & $\begin{array}{l}\text { Number of plants per } \\
1 \mathrm{~m} 2, \text { pcs }\end{array}$ & 394 & 388 & 378 & 3 \\
\hline \multirow{4}{*}{$\begin{array}{l}\text { Milky stage } \\
(07.07 .20)\end{array}$} & Stem height, $\mathrm{cm}$ & 104.3 & 103.4 & 102.3 & 1.2 \\
\hline & $\begin{array}{c}\text { Average weight of dry } \\
\text { stem, g }\end{array}$ & 3.62 & 4.07 & 4.15 & 1.2 \\
\hline & $\begin{array}{c}\text { Secondary root length, } \\
\mathrm{cm}\end{array}$ & 12.0 & 12.0 & 11.5 & 1.2 \\
\hline & $\begin{array}{c}\text { Number of plants per } \\
1 \mathrm{~m} 2, \text { pcs }\end{array}$ & 322 & 344 & 312 & 3 \\
\hline \multirow{5}{*}{$\begin{array}{l}\text { Yellowing } \\
(27.07 .20)\end{array}$} & Stem length, cm & 104.4 & 104.3 & 105.6 & 1.2 \\
\hline & $\begin{array}{c}\text { Average weight of dry } \\
\text { stem, g }\end{array}$ & 3.63 & 4.29 & 4.63 & 1.2 \\
\hline & $\begin{array}{c}\text { Secondary root length, } \\
\mathrm{cm}\end{array}$ & 9.9 & 11.1 & 11.0 & 1.2 \\
\hline & $\begin{array}{c}\text { Number of plants per, } \\
1 \mathrm{~m} 2, \text { pcs }\end{array}$ & 344 & 352 & 319 & 4 \\
\hline & Grain weight per ear, g & 2.0 & 2.4 & 2.8 & \\
\hline
\end{tabular}

Despite the unfavorable weather conditions, the results of the autumn surveys showed that the experimental and control crops were in good physiological condition. All monitored indicators (development phase, plant height, reserves of productive moisture in the arable and 1-meter soil layer, nutrient supply, plant density in autumn and bushiness, depth of tillering node, weediness, damage by pests and diseases) were close to optimal for the agroclimatic zone of the Republic of Tatarstan T.

Phenological observations carried out in the springsummer period of 2020 showed that in the development phase "Tillering-Heading", the plants from the experimental plots showed a more intensive development of the root system than in the control (Table 5). Plants from the experimental plots also had a greater length and weight of the stem, which subsequently led to an increase in the total productivity and bushiness, and the total mass of grain in an ear (Table 5).

Plot harvesting showed that the grain yield had similar values. In the experimental plots it was $1.2 \%$ and $2.5 \%$ higher than in the control (Table 6).

Table 6. Yield of winter wheat

\begin{tabular}{|c|c|c|c|c|}
\hline Variant & $\begin{array}{c}\text { Plot } \\
\text { area, } \\
\text { ha }\end{array}$ & $\begin{array}{c}\text { Gross } \\
\text { harvest, } \\
\text { kg }\end{array}$ & $\begin{array}{c}\text { Productivity, } \\
\text { c/ha }\end{array}$ & LSD 0,5 \\
\hline Control & 3.38 & 16,400 & 48.5 & 1.2 \\
\hline Experiment 1 & 5.94 & 29,160 & 49.1 & 1.3 \\
\hline Experiment 2 & 5.72 & 28,420 & 49.7 & 1.3 \\
\hline
\end{tabular}

Analysis of the obtained grain showed that the mass fraction of protein in the experimental variants differed insignificantly (Table 7). The quality of the wet gluten and the weight of 1,000 seeds were higher in the grain from the experimental plot 1, the hardness and the falling number of grain from the plot of Experiment 2, the 
nature and evenness of the grain was higher in the control.

Table 7. Technological characteristics of winter wheat grain

\begin{tabular}{|c|c|c|c|c|}
\hline Indicators & Control & $\begin{array}{c}\text { Experiment } \\
\mathbf{1}\end{array}$ & $\begin{array}{c}\text { Experiment } \\
\mathbf{2}\end{array}$ & LSD $0_{\mathbf{0}}$ \\
\hline $\begin{array}{c}\text { Mass fraction of } \\
\text { protein, \% }\end{array}$ & 11.9 & 11.8 & 12.0 & 1.2 \\
\hline $\begin{array}{c}\text { Mass fraction of } \\
\text { protein on dry } \\
\text { matter, \% }\end{array}$ & 13.63 & 13.53 & 13.76 & 1.2 \\
\hline $\begin{array}{c}\text { Mass fraction of } \\
\text { crude gluten, \% }\end{array}$ & 24.96 & 24.98 & 24.74 & 1.2 \\
\hline $\begin{array}{c}\text { Mass fraction of } \\
\text { dry gluten, \% }\end{array}$ & 9.44 & 9.34 & 9.49 & 1.2 \\
\hline $\begin{array}{c}\text { Quality of crude } \\
\text { gluten per unit of } \\
\text { the FDM device, \% } \\
\text { Group }\end{array}$ & 74 & 73 & 78 & 2 \\
\hline $\begin{array}{c}\text { Vitreousness, \% } \\
\text { \% }\end{array}$ & 62 & 65 & 72 & 2 \\
\hline Falling number, s & 413 & 419 & 425 & 3 \\
\hline $\begin{array}{c}\text { Moisture content, } \\
\text { \% }\end{array}$ & 12.7 & 12.8 & 12.8 & 1.2 \\
\hline $\begin{array}{c}\text { Weight of 1,000 } \\
\text { seeds, g }\end{array}$ & 39.12 & 38.38 & 39.45 & 1.2 \\
\hline Nature, g/l & 784.9 & 777.6 & 781.2 & 4.6 \\
\hline Evenness, \% & 84.75 & 81.3 & 83.19 & 1.2 \\
\hline
\end{tabular}

The concept of "wheat quality" includes a number of characteristics, which can be conditionally divided into three groups. Group I includes physical indicators: bulk density (nature), mass of 1,000 grains, vitreousness, grain size, evenness, etc. Group II includes chemical indicators: the content of protein, gluten, starch, fiber, soluble carbohydrates, fat, etc. Group III includes the technological properties of flour [19].

The protein content is an important indicator of milling and baking properties of wheat grain. It is related to the quantity and quality of gluten, as well as vitreousness. High quality grain is considered to contain more than $14.5 \%$ protein. Baking qualities of the obtained grain did not differ significantly in the main indicators. However, the main indicator being the ratio of height to diameter in the experimental variants was 19 and $21 \%$ higher, respectively, compared to the control. The resulting grain can be used to make bread.

\section{Conclusion}

1. The use of "Mefosfon" when receiving organic fertilizer from chicken manure accelerates the disinfection process, helps to reduce the maturation of chicken manure.

2. Experimental data show that the use of organic fertilizer UP-1 in growing winter wheat accelerates the development of plants, increases their resistance to unfavorable environmental factors, contributes to an increase in the mass and tillering of plants, the total mass of grain in an ear, and provides a slight increase in yield.

3 . The grain obtained from the plots with the applied organic fertilizer UP-1 has the quality not worse than when using compost chicken manure, which is widely used as an organic fertilizer.

\section{References}

1. H.Y. Ch'ng, O.H. Ahmed, S. Kassim, N.M.A. Majid, Recycling of Sago (Metroxylonsagu) Bagasse with Chicken Manure Slurry through Cocomposting, J. of Agricult. Sci. and Technol., 16(6), 1441-1454 (2014)

2. I.Kh. Gaifullin, B.G. Ziganshin, A.I. Rudakov, Yu.Kh. Shogenov, The relevance of the use of biogas plants in Russia and abroad, Bull. of the Kazan State Agrar. Univ., 71-73 (2018)

3. I.Kh. Gaifullin, B.G. Ziganshin, A.I. Rudakov, Yu.Kh. Shogenov, The use of fermented waste from a biogas plant as an organic fertilizer, II Int. Sci. and Pract. Conf. dedicated to the memory of Doctor of Technical Sciences, Professor I.E. Volkov, Agricultural science of the XXI century (Publishing house Kazan GAU, Kazan, 2017), pp. 13-16

4. R.I. Ibyatov, F.Sh. Shaikhutdinov, A.R. Valiev, Analysis of the yield of spring wheat by the method of principal components, Grain econ. of Russ., 2(50), 17-22 (2017)

5. Kh.V. Gibadullina, I.G. Khabibullin, Z.M. Khaliullina, R.R. Akhmetzyanov, Chemical aspects of sulfur transformation in soil, Bull. of Kazan State Agrar. Univ., 4(3(13)), 97-99 (2009)

6. I. Vidovic, L. Sochorcova, Vjhyv potencialnej smeny klimy na urody zrna pseni ce Zetner F. Ozimnej (triticum aestivum) v podmienkach kukuricnej virobnej oblasti Slovenka, Agricult., 50(10/12), 187-198 (2014)

7. M.Yu. Gilyazov, B.R. Yunusov, Variability of the chemical composition of the yield and the normative removal of nutrients in winter rye under the influence of agrochemicals, Bull. of Kazan State Agrar. Univ., 4(47), 24-28 (2017)

8. F.S. Sibagatullin, Z.M. Khaliullina, A.M. Petrov, K.O. Sinyashin, Prospects for the use of various commercial drugs to accelerate the process of "ripening" of chicken droppings, Bull. of the Kazan State Agrar. Univ., 14(1(52)), 53-57 (2019)

9. F.S. Sibagatullin, Z.M. Khaliullina, A.R. Safiullina, A.M. Petrov, K.O. Sinyashin, M.V. Shulaev, Study of fermentation processes of poultry manure under the influence of a biologically active additive "MEFOSFON", Bull. of the Kazan State Agrar. Univ., 48(2), 42-47 (2018)

10. R.R. Akhmetzyanova, Reception of increasing the seed productivity of alfalfa, Bull. of Kazan State Agrar. Univ., 11(3(41)), 5-8 (2016)

11. R.R. Akhmetzyanov, I.G. Khabibullin, Kh.S. Faskhutdinov, H.V. Gibadullina, Lowtemperature method of obtaining materials from waste heat and petrochemical enterprises, Bull. of the Moscow State Agroeng. Univ. named after V.P. Goryachkin, 4(35), 34-36 (2009) 
12. M.Yu. Gilyazov, A.A. Lukmanov, M.R. Muratov, Long-term use of fertilizers and arable land productivity (Kazan Univ. Publ. House, Kazan, 2016), $220 \mathrm{p}$.

13. A.S. Mikhailov, R.R. Akhmetzyanov, Kh.S. Faskhutdinov, Yu.I. Fedorov, Thermodynamic evaluation of antifriction materials, Bull. of Kazan Technol. Univ., 15(14), 87-89 (2012)

14. F. Khaliullin, R. Akhmetzyanov, F. Arslanov, Yu. Korepanov, Method for determining remaining life of engine by dynamic characteristics, Coll. Engineering for rural development (2020), pp. 1096-1101

15. F.Sh. Shaikhutdinov, I.M. Serzhanov, R.V. Minikayev, D.Kh. Zinnatullin, Peculiarities of photosynthetic activity of dicoccum (spelled) wheat plants at different sowing dates, predecessors and nutritional background, Bull. of the Kazan State Agrar. Univ., 52(1), 58-64 (2019)

16. R.R. Akhmetzyanova, Kh.Z. Karimov, Reception of increasing seed productivity, sowing qualities and yielding properties of variegated alfalfa, Bull. of the Omsk State Agrar. Univ., 1(25), 5-10 (2017)

17. B.A. Dospekhov, Field experiment methodology (with the basics of processing research results), 5th ed., add. and revised (Agropromizdat, Moscow, 1985), $351 \mathrm{p}$.

18. GOST R 53117-2008, Organic fertilizers based on animal waste. Technical conditions.

19. S.V. Zverev, Physical properties of grain and products of its processing (DeLiprint, Moscow, 2007), $176 \mathrm{p}$. 